Pesq. Vet. Bras. 38(1):175-182, janeiro 2018 DOI: $10.1590 / \mathrm{S} 0100-736 \mathrm{X} 2018000100027$

\title{
Estimation, morphometry and ultrastructure of ovarian preantral follicle population in agouti (Dasyprocta leporina) ${ }^{1}$
}

\author{
Erica A.A. Santos², Gabriela L. Lima ${ }^{3}$, Erica C.G. Praxedes², Andréia M. Silva², Keilla \\ M. Maia ${ }^{2}$, Moacir F. Oliveira ${ }^{2}$, Ana Paula R. Rodrigues ${ }^{4}$ and Alexandre R Silva ${ }^{2 *}$
}

\begin{abstract}
Santos E.A.A., Lima G.L., Praxedes E.C.G., Silva A.M., Maia K.M., Oliveira M.F., Rodrigues A.P.R. \& Silva A.R. 2018. Estimation, morphometry and ultrastructure of ovarian preantral follicle population in agouti (Dasyprocta leporina). Pesquisa Veterinária Brasileira 38(1):175-182. Laboratório de Conservação de Germoplasma Animal, Universidade Federal Rural do Semi-Árido, BR-110 Km 47, Presidente Costa e Silva, Mossoró, RN 59625-900, Brazil. E-mail: legio2000@yahoo.com

The aim of this study was to characterize the preantral ovarian follicular population in agoutis ( $D$. leporina) by estimating the number of follicles at each developmental category, and also describe the morphometry and the specific features of the follicle and the oocyte by using light and transmission electron microscopy. The length of each ovary was measured using a caliper rule, longitudinally sectioned into two halves and both were immediately fixed to perform the estimation of follicular population and ultrastructural analysis. The mean ( \pm S.E.M.) population of follicular per pair of ovary was estimated at $4419.8 \pm 532.26$ and $5397.52 \pm 574.91$ for right and left ovaries, respectively, but no differences were observed between them. The diameters for follicles, oocyte and nuclei were: $18.62 \pm 3.40 \mu \mathrm{m}, 12.28 \pm 2.37 \mu \mathrm{m}$ and $6.10 \pm 0.93 \mu \mathrm{m}$ for primordial, $23.75 \pm 5.70 \mu \mathrm{m}, 14.22 \pm 3.00 \mu \mathrm{m}$ and $6.70 \pm 1.24 \mu \mathrm{m}$ for primary and $88.55 \pm 17.61 \mu \mathrm{m}, 52.85 \pm 17.56 \mu \mathrm{m}$ and $22.33 \pm 17.61 \mu \mathrm{m}$ for secondary follicles, respectively. The most of the follicles found belonged to the primordial category $(86.63 \%)$, followed by primary (13.01\%) and secondary (0.35\%) one. Additionally, polyovular follicles were observed in all the animals and they represented $7.51 \%$ of the total follicles counted. The ultrastructural analysis showed that the oocyte presented a central and regular nuclei, displaying a homogenous mass. Among the organelles, the mitochondria were the most abundant and the oocyte Golgi apparatus was rarely observed. In conclusion, this work shows for the first time the characterization of the population of preantral follicles in the ovary of Dasyprocta leporina. Those information will be useful for further development and adaptation of biotechniques such as germplasm cryopreservation and in vitro gametes manipulation.
\end{abstract}

INDEX TERMS: Morphometry, ultrastructure, ovarian preantral follicles, agouti, Dasyprocta leporine, ovarian tissue, follicles.

RESUMO.- [Morfometria, estimativa e ultraestrutura da população folicular ovariana preantral de cutia (Dasyprocta leporina).] 0 objetivo deste trabalho foi caracterizar a população folicular ovariana pré-antral em cutias $(D$.

\footnotetext{
${ }^{1}$ Received on June 23, 2017.

Accepted for publication on August 2, 2017.

${ }^{2}$ Laboratório de Conservação de Germoplasma Animal, Universidade Federal Rural do Semi-Árido (Ufersa), BR-110 Km 47, Presidente Costa e Silva, Mossoró, RN 59625-900, Brazil. *Corresponding author: legio2000@ yahoo.com

${ }^{3}$ Departamento de Medicina Veterinária, Universidade Federal de Roraima, Campus Cauamé, BR-174 KM 12, Monte Cristo, Boa Vista, RR 69300000, Brazil.

${ }^{4}$ Laboratório de Manipulação de Oócitos e Folículos Pré-antrais, Universidade Estadual do Ceará, Av. Paranjana, 1700, Itaperi, Fortaleza, CE, Brazil.
}

leporina) estimando o número de folículos em cada categoria de desenvolvimento, e também descrever a morfometria e as características específicas do folículo e oócito usando microscopia de luz e eletrônica de transmissão. O comprimento de cada ovário foi medido utilizando um paquímetro, seccionados longitudinalmente em duas metades e ambos foram imediatamente fixados para realizar a estimativa da população folicular e análise ultraestrutural. A média $( \pm$ S.E.M.) da população folicular por par de ovário foi estimada em $4419,8 \pm 532,26$ e 5397,52 $\pm 574,91$ nos ovários direito e esquerdo, respectivamente, mas não foram observadas diferenças entre eles. Os diâmetros dos folículos, oócito e núcleos, respectivamente, foram: $18,62 \pm 3,40 \mu \mathrm{m}, 12,28 \pm 2.37 \mu \mathrm{m}$ e $6,10 \pm 0,93 \mu \mathrm{m}$ para primor- 
dial, $23,75 \pm 5,70 \mu \mathrm{m}, 14,22 \pm 3,00 \mu \mathrm{m}$ e $6,70 \pm 1,24 \mu \mathrm{m}$ para primário e $88,55 \pm 17,61 \mu \mathrm{m}, 52,85 \pm 17,56 \mu \mathrm{m}$ e $22,33 \pm 17,61 \mu \mathrm{m}$ de folículos secundários. A maioria dos folículos encontrados pertencia à categoria primordial $(86,63 \%)$, seguido pelo primário $(13,01 \%)$ e um secundário $(0,35 \%)$. Adicionalmente, os folículos poliovulares foram observados em todos os animais e representavam 7,51\% do total de folículos contados. A análise ultra-estrutural mostrou que o oócito apresentou núcleos centrais e regulares, exibindo uma massa homogênea. Dentre as organelas, as mitocôndrias foram as mais abundantes e o aparelho de Golgi do oócito foi raramente observado. Em conclusão, este trabalho mostra pela primeira vez a caracterização da população de folículos pré-antrais do ovário da Dasyprocta leporina. Essas informações serão úteis para o desenvolvimento e adaptação de biotécnicas, como a criopreservação de germoplasma e manipulação de gametas in vitro.

TERMOS DE INDEXAÇÃO: Morfometria, ultraestrutura, população folicular ovariana preantral, cutias, Dasyprocta leporina, tecido ovariano, folículos.

\section{INTRODUCTION}

The agouti (Dasyprocta sp.) is a Neotropical hystricomorph rodent of the Caviidae family that presents an important role on the spread of many plant species. Due to the interest on its meat and the destruction of it habitat, its population has been reduced along the years (Hosken \& Silveira 2001). In this context, captive breeding programs are important not only for providing an alternative source of protein for humans, but also for preserving the species (Nogueira \& Nogueira-Filho 2011). Besides, conservative studies conducted in non-threatened agouti species such as Dasyprocta leporina could be extrapolated for those endangered ones such as the D. ruatanica, D. coibae and D. mexicana (IUCN 2016).

In order to improve its performance under captivity, several studies are focusing on the improvement of knowledge about the reproductive biology of the agouti, such as placentation (Rodrigues et al. 2003) and morphological and morphometric studies of female reproductive organs (Almeida et al. 2003, Fortes et al. 2005). However, reports concerned on the development and application of biotechniques are still scarce (Mollineau et al. 2008, Silva et al. 2011, Castelo et al. 2014), especially those focused on females (Wanderley et al. 2012). Thus, the development of studies related to the quantitative and qualitative aspects of ovarian follicles population, reported to other rodent's species as Spix's yellow-toothed cavy - Galea spixii (Praxedes et al. 2015) and Coypu - Myocastor coypus (Felipe et al. 1999) could contribute to the efforts for the formation of cryobanks derived from female genetic material.

In this context, the knowledge of specific morphometric and ultrastructural characteristics of ovarian follicles is a significant step toward the development of reproductive technologies, mainly those involving pre-antral follicles (PFs) (Lopes et al. 2006). The PFs are a great source of female germplasm and represents about $95 \%$ of the ovarian follicles, being possible the use of this source in many assisted reproductive techniques (Jimenez et al. 2016). Once ovary of the hystricomorphs has marked interspecific variation (Weir \& Rowlands 1974), it is important to quantify and characterize the D. leporina PFs and it will be useful for the development of future technologies to preserve this species and its preservation would contribute to the efforts to form cryobanks (Santos et al. 2010).

The aim of this research was to characterize the preantral ovarian follicular population in agoutis (D. leporina) by estimating the number of follicles at each developmental category, and to describe the morphometry and the specific features of the follicle and the oocyte by using light and transmission electron microscopy.

\section{MATERIALS AND METHODS}

Animals. The ethics committee of the UFERSA approved the experimental protocols as well as the animal care procedures used (Process no 23091.002752/2011-08). The animals belonged to the Centre of Multiplication of Wild Animals from UFERSA (Mossoró, RN, Brazil; $5^{\circ} 10^{\prime} \mathrm{S}, 37^{\circ} 10^{\prime} \mathrm{W}$ ). The climate is typical semiarid, with an average annual temperature of $27^{\circ} \mathrm{C}$. Nowadays, this center shelters a population of 180 Dasyprocta leporina individuals, and a programmed slaughter is conducted every year for population control. The animals are destined for several experiments. For the present research, a total of 11 mature females aging 2.5 years old, weighting $2.42 \pm 0.19$ (minimal 2.21 and maximal $2.70 \mathrm{~kg}$ ) were used. The animals were kept in captivity and were fed with fruits, balanced ration produced at UFERSA and water ad libitum.

Source and preparation of ovaries. Pairs of ovaries from females agouti $(n=11)$ were removed aseptically following slaughtering. The ovaries were rinsed once with $70 \%$ ethanol for 10 $\mathrm{s}$, twice in sterile phosphate-buffered saline (PBS) and eventual corpora lutea were excised using a scalpel. The length of each ovary was measured using a caliper rule. Ovaries were cut longitudinally into two halves that were immediately fixed in Carnoy for 4 hours.

Histological analysis. After fixation in Carnoy for 4 hours, the ovarian half was dehydrated in a graded series of ethanol, clarified with xylene, embedded in paraffin wax and serially sectioned at $7 \mu \mathrm{m}$. Every $60^{\text {th }}$ section was mounted on glass slides, stained with hematoxylin-eosin and evaluated by light microscopy at a $100 \times$ magnification (Carl Zeiss Optical Inc., Chester, USA). Preantral follicles presenting visible nuclei were defined as an oocyte surrounded by either one layer of flattened or cuboidal granulosa cells, or several layers of cuboidal granulosa cells with no antrum and classified as primordial, primary and secondary according to Silva et al. (2004). At the evaluation moment, images were recorded by microphotographs.

Follicular population estimation. The entire ovary was used to perform the estimation of follicular population. The preantral follicles were counted for quantitative assessment in all the glass slides. The follicular measurements were conducted by using an ocular micrometer. The average of two perpendicular measurements from the outer layer of granulosa cells and of the oocyte was used as a measurement of follicle and oocyte diameter, respectively. The measurements were made only on follicles with a visible oocyte nucleus. The PF population was estimated by using a formula described by Lucci et al. (1999), based on a correction factor reported by Gougeon \& Chainy (1997). The formula is described as follows:

PF Population = № of follicles X № of sections obtained $\mathrm{x}$ Thickness of sections № of sections observed x Mean of oocyte nuclei diameter. 
Assessment of preantral follicles integrity. The PFs were identified and classified by light microscopy (100x) according to their integrity. Follicular morphology was evaluated based on the integrity of the oocyte, granulosa cells and basement membrane. PFs were classified and counted as morphologically normal, when the oocyte nucleus and an intact oocyte was present surrounded by granulosa cells that were well organized in one or more layers , and organized layers of granulosa cells, or atretic, when the oocyte exhibited pycnotic nucleus and/or ooplasma shrinkage, and occasionally granulosa cell layers became disorganized, and/or included enlarged cells. To avoid evaluating and counting a follicle more than once, preantral follicles were analyzed only in the sections where oocyte nucleus were observed (Lopes et al. 2009).

Ultrastructural analysis. To better examine the follicular morphology, transmission electron microscopy (TEM) was performed to analyze the PF ultrastructure, according to Oliveira et al. (2008) with some modifications. A portion with a maximum dimension of $1 \mathrm{~mm}^{3}$ was cut from the ovary and fixed in glutaraldehyde solution $0.1 \mathrm{M}\left(\mathrm{pH} \mathrm{7.2)}\right.$ at room temperature (RT, approximately $25^{\circ} \mathrm{C}$ ). Further, specimens were post-fixed in $2 \%$ osmium tetroxide, in $0.1 \mathrm{M}$ sodium cacodylate buffer for $2 \mathrm{~h}$ at RT. The samples were then dehydrated in ethanol (three washes of $15 \mathrm{~min}$ at each one), followed by two washes of $15 \mathrm{~min}$ at propylene oxide. After this, samples were embedded in a propylene oxide and Spurr's resin solution (1:1) for $8 \mathrm{~h}$, thereafter maintained in Spurr's epoxy resin, overnight. Then, specimens were embedded in Spurr's resin at $60^{\circ} \mathrm{C}$ for $48 \mathrm{~h}$, after that they were kept at room temperature. Semi-thin sections $(0.5 \mu \mathrm{m})$ were cut, stained with toluidine blue and analyzed by light microscopy at a 400x magnification. Ultra-thin sections $(60-70 \mathrm{~nm})$ were obtained from preantral follicles classified as morphologically normal in semi-thin sections, according to the criteria adopted in histology. Subsequently, ultra-thin sections were contrasted with uranyl acetate and lead citrate and examined under a Morgagni 268 D (FEI Company, Hillsboro, USA) transmission electron microscopy operating at $80 \mathrm{kV}$.

Statistical analysis. Eleven replicates were conducted. The comparison of follicular population among the follicular classes, as well as the comparisons of diameters of follicles, oocytes and oocyte's nuclei among the follicular classes were performed by ANOVA one way. Data were expressed as mean and standard error of means (SEM). Values were considered statistically significant when $\mathrm{p}<0.05$.

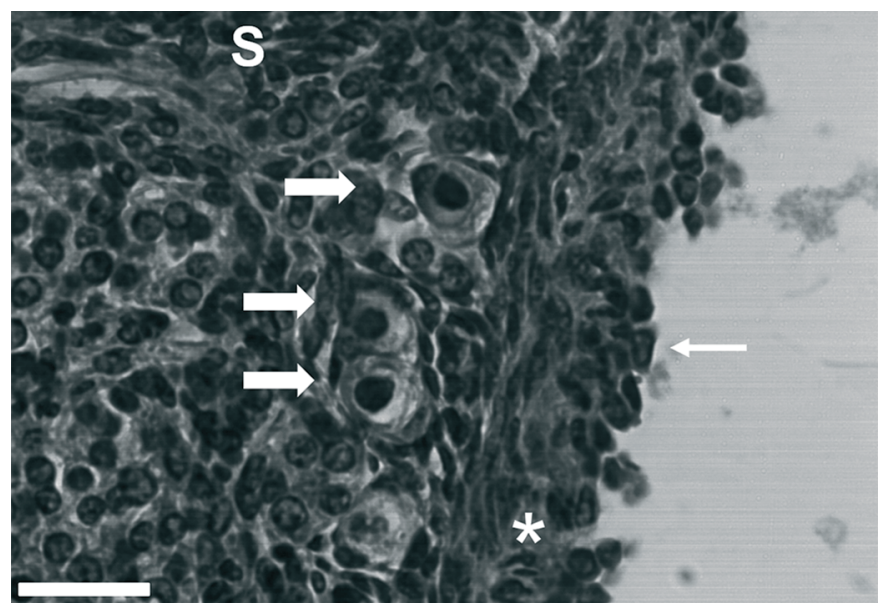

Fig.1. Histological assessment of ovary of Dasyprocta leporina. Germinative epithelium (arrow), tunica albuginea $(*)$, stroma (S) and follicles (full narrows). 40x. Scale bar $=50 \mu \mathrm{m}$.

\section{RESULTS}

The mean of the length of the left and the right ovary was $1.05 \pm 0.09$ and $1.04 \pm 0.07 \mathrm{~cm}$ respectively. The Dasyprocta leporina ovaries were characterized as ovoid bodies, relatively symmetric, with a smooth surface where the growing follicles were observed as translucids bodies.

At histology, the ovary present one external layer of cuboidal cells, characterizing the germinative epithelium. Immediately below, a region formed by dense conjunctive tissue, with a few blood vessels, the tunica albuginea, was observed. Below this, there was a layer of conjunctive tissue forming the stroma, which contains the follicles. Scattered smooth muscle fibers appeared in the stroma around the follicles (Fig.1). All females had at least one functional corpora lutea (CL) and a higher number of accessory CL, characterized by the presence of an inner oocyte or remnants of zona pelucida and its smaller-size compared to functional CL.

The primordial follicles (Fig.2A) were characterized by an oocyte surrounded by one layer of squamous or squamous-cuboidal granulosa cells. These primordial follicles

Fig.2. Histological features of agouti (Dasyprocta leporina) ovary. (A) Primordial follicles (arrows) displaying an oocyte with a large nucleus, surrounded by one layer of flattened cells. (B) Primary follicle (arrows) characterized by an oocyte displaying a large nucleus and homogenous cytoplasm surrounded by one complete layer of cuboidal granulosa cells. (C) Secondary follicle showing two or more layers of cuboidal granulosa cells. Note the theca interna formed by elongated and fusiform cells appearing as concentric layers externally at the granulosa layers. (D) Polyovular follicles (arrow) containing two oocytes surrounded by only one layer of granulosa cells. Scale bar $=50 \mu \mathrm{m}$.

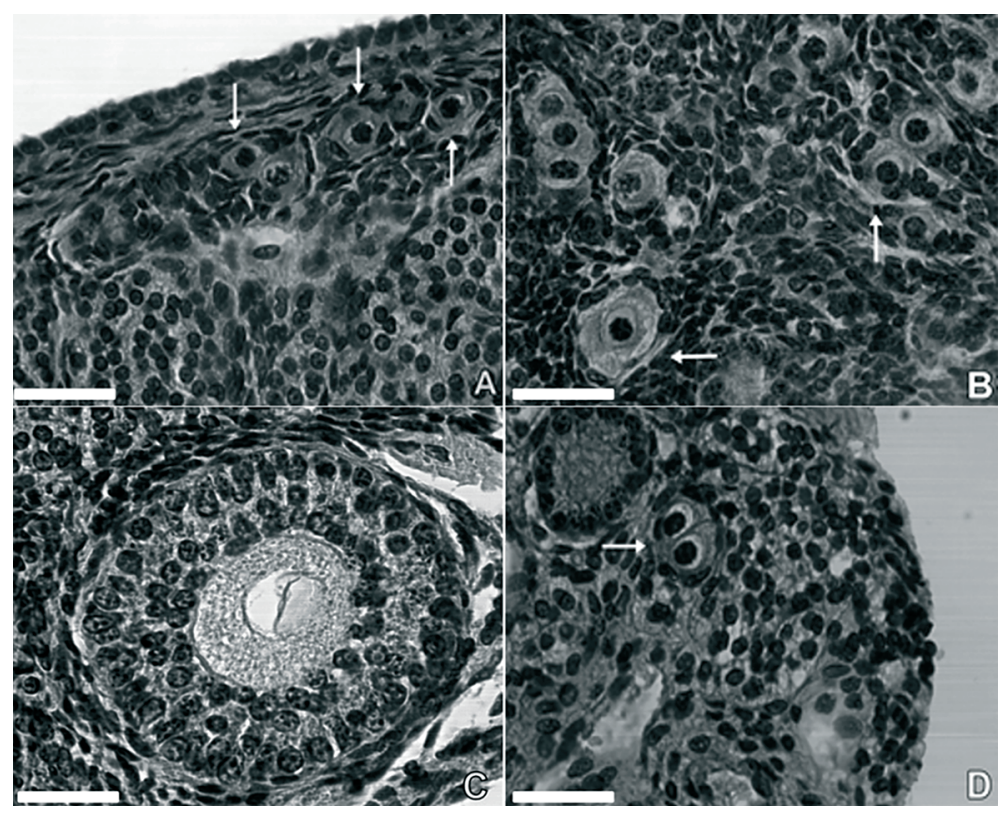


Table 1. Estimation of ovarian preantral follicular population (Mean \pm standard error) in agoutis (Dasyprocta leporina)

\begin{tabular}{|c|c|c|c|c|c|}
\hline \multirow[t]{2}{*}{$\begin{array}{c}\text { Follicle } \\
\text { category }\end{array}$} & \multicolumn{2}{|c|}{$\begin{array}{c}\text { Follicle population } \\
\text { (Mean } \pm \text { standard error) }\end{array}$} & \multirow[t]{2}{*}{$\begin{array}{c}\text { Minimum } \\
\text { - Maximum }\end{array}$} & \multicolumn{2}{|c|}{$\begin{array}{l}\text { Percentage of follicles } \\
(\%)\end{array}$} \\
\hline & Right & Left & & Right & Left \\
\hline Primordial & $3692.94 \pm 467.61^{\mathrm{a}}$ & $4744.2 \pm 543.17^{\mathrm{a}}$ & $305.17-2198.84$ & 85.51 & 87.76 \\
\hline Primary & $708.63 \pm 129.37^{b}$ & $683.27 \pm 96.41^{\mathrm{b}}$ & 11.09-343.89 & 14.12 & 11.90 \\
\hline Secondary & $18.23 \pm 3.79^{c}$ & $15.05 \pm 6.56^{c}$ & $0-20.63$ & 0.37 & 0.34 \\
\hline Total & $4419.8 \pm 532.26$ & $5397.52 \pm 574.91$ & $1123.19-3692.22$ & 100.00 & 100.00 \\
\hline
\end{tabular}

Table 2. Diameter of ovarian preantral follicles, oocytes and its nuclei $(\mu \mathrm{m})$ in agoutis (Dasyprocta leporina), according to follicle categories (Mean \pm standard error)

\begin{tabular}{lccc}
\hline Category & Follicle & Oocyte & Nuclei \\
\hline Primordial & $18,62 \pm 3,40 \mathrm{~B}$ & $12,28 \pm 2,37^{\mathrm{C}}$ & $6,10 \pm 0,93^{\mathrm{C}}$ \\
Primary & $23,75 \pm 5,70^{\mathrm{B}}$ & $14,22 \pm 3,00^{\mathrm{B}}$ & $6,70 \pm 1,24^{\mathrm{B}}$ \\
Secondary & $88,55 \pm 17,61^{\mathrm{A}}$ & $52,85 \pm 17,56^{\mathrm{A}}$ & $22,33 \pm 17,61^{\mathrm{A}}$
\end{tabular}

$\overline{\mathrm{A}, \mathrm{B}, \mathrm{C}}$ At the same row different superscript demonstrates significant differences $(\mathrm{P}<0.05)$.

were found in the cortex just beneath the tunica albuginea. Primary follicles (Fig.2B) were situated in the periphery of the cortex, presenting a single layer of cuboidal granulosa cells surrounding the oocyte. Secondary follicles (Fig.2C) had an oocyte surrounded by two or more concentric layers of cuboidal granulosa cells; between those structures, the zona pellucida was observed. Externally the granulosa cells, the internal theca was formed by elongated and fusiform cells appearing as concentric layers.

Polyovular PFs were observed in all the animals and they were more frequently present in primordial follicles. They represented $7.51 \%$ of the total PFs counted (Fig.2D).

A total of $4419.8 \pm 532.26$ and $5397.52 \pm 574.91$ PFs were estimated as the population in right and left ovary of D. leporina respectively, but no differences were observed between them. The follicular population in each category was also estimated and the results are shown in Table 1. It was verified differences among all the categories. The most of the follicles found belonged to the primordial category $(86.63 \%)$, followed by primary $(13.01 \%)$ and secondary

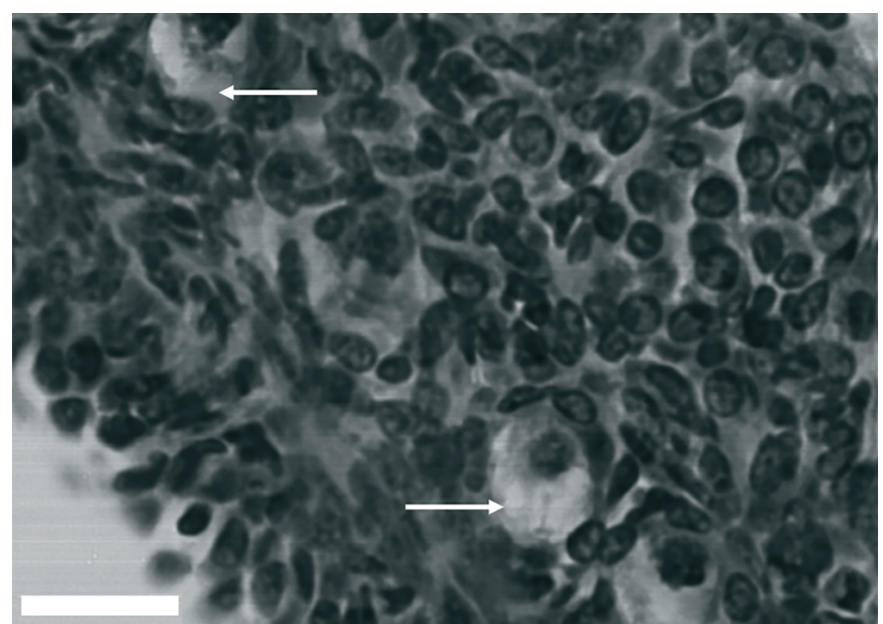

Fig.3. Histological features of agouti (Dasyprocta leporina) ovary. Atretic follicles presenting oocyte shrinkage (arrows). Scale bar $=50 \mu \mathrm{m}$.
$(0.35 \%)$ ones. According to the follicular measurements, secondary PFs presented larger diameter of follicle, oocyte and nucleus than the other PFs (Table 2).

The vast majority of PFs were morphologically normal (70.78\%) and only 29.22\% were atretic (Fig.3). Morphologically normal PFs showed a spherical oocyte with a large (eosinophilic) central or eccentric nucleus and uniform cytoplasm. Granulosa cells without pycnotic nuclei were well-organized in layers surrounding the oocyte, and a distinguishable intact basement membrane was observed. Atretic follicles showed a retraced oocyte with or without a pycnotic nucleus (Fig.3). Granulosa cells remained unaltered or became disorganized, and they were sometimes swollen and/or detached from the basement membrane. Occurrence of pycnotic bodies in granulosa cells or rupture of the basement membrane were not observed.

The electron microscopy study revealed that initial PFs contain immature oocytes presenting a distinct nucleus, with a very regular aspect. The chromatin is arranged as euchromatin; however, few heterochromatin clumps were found scattered through the nucleus mainly near nuclear membrane. The nucleolus was distinct and central. The oocyte cytoplasm showed several rounded mitochondria dispersed through it and some vacuoles and the Golgi apparatus was well developed and concentrated in one pole of the cell. (Fig.4).

Lipid droplets were common and few profiles of endoplasmic reticulum were found, associated with it and with mitochondria. Flattened or cuboidal granulosa cells as-

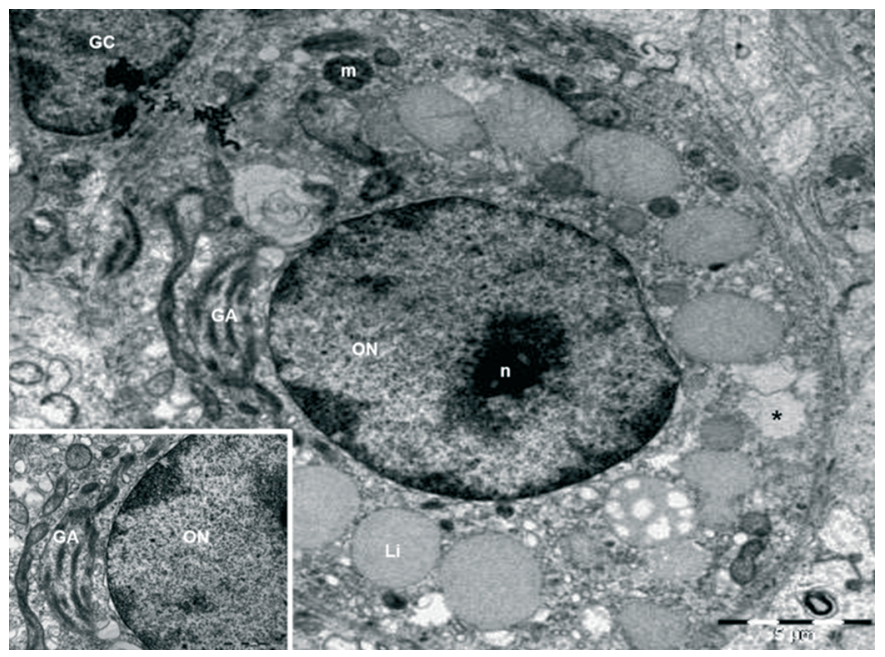

Fig.4. Electron micrographs of preantral ovarian follicles of Dasyprocta leporina. Note the presence of oocyte nuclei $(\mathrm{ON})$, nucleolus (n), lipid droplets (Li), mitochondria (m), Golgi apparatus $(\mathrm{GA})$, vacuoles $\left(^{*}\right)$, and a granulosa cell $(\mathrm{GC})$. 


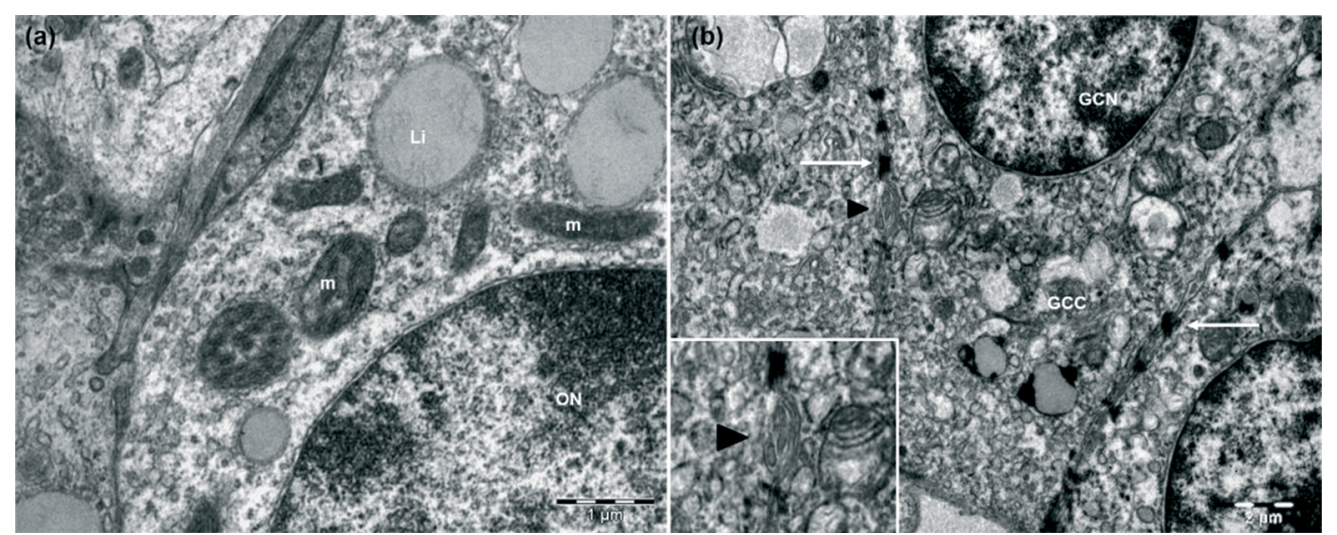

Fig.5. Electron micrographs of Dasyprocta leporina ovarian follicles. (a) ON = oocyte nuclei, Li = lipid droplets, mitochondria (m). (b) GCN = granulosa cell nuclei, GCC = granulosa cell cytoplasm, intercellular junctions (arrows) between granulosa cells; pinocytotic vesicles from one GC the other (arrowhead).

sociated with the oocyte presented a dark nucleus where heterochromatin was abundant; the granulosa cells (GC) cytoplasm was dark due to several free ribosomes, mitochondria was also common. In addition, some intercellular junctions between GCs, presenting electron-dense aspect were observed. Also pinocytotic vesicles protrude into the ooplasm from one GC the other (Fig.5).

\section{DISCUSSION}

The present study is the first research characterizing and estimating the ovarian preantral follicle population in one (Dasyprocta leporina) from the various agouti species. The agouti ovary presented yellow color, with a smooth surface containing translucent areas suggestive of developing follicles, in which corpora lutea and growing follicles did not protrude above the surface, similar to the previously descriptions in the same species (Almeida et al. 2003) and in paca (Cuniculus paca, Reis et al. 2011). The constituent cell types of the D. leporina ovary were similar to those described for other hystricognath rodents (Praxedes et al. 2015), including the wild black agouti (Dasyprocta fuliginosa, Mayor et al. 2011).

Although the presence of a great amount of interstitial tissue among the agouti ovary was observed, there was no evidence of the hypertrophied interstitial gland cells as described for other rodents such as the viscacha (Lagostomus maximus, Gil et al. 2007) and the chinchilla (Chinchilla lanigera, Sánchez-Toranzo et al. 2014). Almeida et al. (2003) previously described the absence of those structures in D. agouti.

A large amount of accessory CLs was verified in agoutis, as described for plains viscacha (Jensen et al. 2006), paca (Reis et al. 2006), and chinchillas (Sánchez-Toranzo et al. 2014). Such structures were previously identified by Weir (1971) that distinguished accessory from functional CLs by the smaller size and presence of a degenerating oocyte or remnants of the zona pellucida. Its origin is well documented in wild black agoutis, being suggested that some antral follicles are selected to complete its growth and after ovulation, these follicles luteinize resulting in functional CL, while many follicles from which ovulation did not occur will transform to accessory CL by luteinization of the membrane granulosa (Mayor et al. 2011). The authors hypothesized that the presence of accessory CL is important for the maintenance of gestation and maybe essential for the continuous hormonal production. Studies related to the role of the accessory CLs on the progesterone profile in $D$. leporina pregnancy are still required.

The PF population found for D. leporina is greater than that reported for other hystricognath rodent, the Galea spixii cavy (416.0 \pm 342.8 follicles - Praxedes et al. 2015). Also in cavy species, the great majority of PFs were classified as primary ones (63.7\%), different to that found for agoutis in which most of PFs were primordial. This is an evidence of an interspecific variation, as previously suggested by Weir \& Rowlands (1974) for the reproductive aspects of hystricomorphic rodents. Moreover, the variation found among agouti individuals regarding their PF population is largely different from that described for mice, which varies from 2,000 (Mcclellan et al. 2003) to 10,000-15,000 PFs per ovarian pair (Dean 2002) in adult individuals. These discrepancies may be attributed to the phylogenetic distance between agoutis and mice that belong to different infraorders (Reis et al. 2006). Despite valuable studies regarding ovarian characteristics of hystrichomorphics (Mayor et al. 2011, Santos et al. 2014) were reported, little information is available regarding its PFs population, making it difficult to confront the results obtained. Further studies are required to investigate the relation between the PF population and the ovulation rate, once this information is not available.

In agoutis, a relative high atresia rate was found $(29.22 \%)$, when compared to other rodents as the cavies (5.4\%; Praxedes et al. 2015). In fact, as previously described for mice, the selection of potentially ovulatory follicles occurs before the antral phase of follicular development, which may be possible related to the PF population and atresia rate. Moreover, individuals with a reduced follicular population usually present low rates of follicular atresia and high rates of follicular recruitment (Campos-Júnior et al., 2012). These statements could explain the high atresia rate in agoutis, since the species presents an elevated PF population, but only a low number of growing follicles, when compared to other hystricognath rodent, the cavy (Praxedes et al. 2015). 
As in other rodent species as the chinchilla (Sánchez-Toranzo et al. 2014) and the cape porcupine - Hystrix africaeaustralis (Van Aarde \& Skinner 1986), most of the follicles observed in agoutis consisted of a large reserve of quiescent primordial follicles and only a small number of PFs were in the growing phase. The smallest follicles (primordial and primary) were arranged as groups, forming clusters within the connective tissue, similarly as described for rats (Hirshfield 1989) and chinchillas (Sánchez-Toranzo et al. 2014). It is well known that the ovarian cortex contains thousands to millions of primordial follicles that constitute the ovarian reserve from which follicles are engaged for development (Paulini et al. 2014).

The presence of polyovular PFs was verified in the ovaries of agouti. In mammalian species the majority of ovarian follicles usually contain only one oocyte, but the presence of follicles containing more than one oocyte has been described in many species, including some rodents as the plains viscacha (Flamini et al. 2009), and the chinchilla (Sánchez-Toranzo et al. 2014). These follicles may form during the earliest stages of follicle differentiation, due to an imbalance between somatic and germinal cells, which induces an incomplete germ cell cyst breakdown. In polyovular follicles, the quality of the various oocytes is often heterogeneous. Numerous authors reported that polyovular follicles are able to reach ovulation and ovulate (Reynaud et al. 2010), but their destiny in agoutis remains to be elucidated.

Regarding morphometry, we verify that agoutis PFs present a smaller follicle, oocyte and nuclei diameter than those reported for other rodents, as the coypu (Felipe et al. 1999), and the chinchilla (Sánchez-Toranzo et al. 2014). However, it is similar to the cavies' PFs diameter (Praxedes et al. 2015). These statements evidence the marked interspecific variation reported for hystricomorphic rodents with respect to their reproductive features (Weir \& Rowlands 1974).

The ultrastructural analysis showed that the agouti oocyte presented a central and regular nuclei, displaying a homogenous mass, similar to the features described for mice (Chouinard 1971), but different from hamster (Takeuchi et al. 1984) and rat (Antoine et al. 1987), in which the oocyte nucleoli become a compact homogenous mass at the antral follicle stage (Sutovskỳ et al. 1993). It was previously reported that nucleolar compaction during oogenesis does not occur at the same stage in all species and those differences are correlated with a decrease in RNA synthesis along the follicular development (Antoine et al. 1989). The chromatin compartmentalization is related to the ribonucleoprotein and deoxyribonucleoprotein activities and to the nuclear organization of gene expression (Zuccotti et al. 2005).

The organelles were uniformly distributed throughout the oocyte cytoplasm. This characteristic was different from those described for mouse oocytes within germ cell cysts and primordial follicles, which presented groups of organelles close to the nucleus, named Balbiani bodies. The round-shaped mitochondria was the most abundant organelle found in D. leporina oocytes, in fact, the germinal vesicle stage oocytes commonly possess round-shaped mitochondria (Eichenlaub-Ritter et al. 2011) which are kno- wn to be an immature form of mitochondria and develop to an elongated shape as they become mature (Fair et al. 1997). This organelle plays functional relationships with other organelles during maturation and early development (Dumollard et al. 2004). Studies indicate a physiological relationship between mitochondria and endoplasmic reticulum, in which the mitochondria would provide energy for the regrowth and activity of endoplasmic reticulum (Bernhard \& Rouiller 1956). In most mammalian species, it is common the association of these organelles and lipid droplets, which was also an abundant organelle in agouti. Biochemical studies demonstrated the requirement of enzymatic activity associated with the endoplasmic reticulum and mitochondria in the synthesis of lipids, such as those stored on lipid droplets (Raturi \& Simmen 2013).

As described for another hystricognath rodent, (Praxedes et al. 2015), Golgi apparatus of oocytes enclosed in $D$. leporina PFs is rare, but when found, they were well developed and located in one pole of the cell. According to Mondadori et al. (2010), the location of this organelle into the oocyte varies according to the follicle development and it appears to be more developed in growing follicles than in the early PFs, consistent with the higher metabolism and requirement for protein and lipids of those oocytes (Paulini et al. 2014).

Some electron-dense structures connecting granulose cells were identified by TEM in agoutis early PFs. The presence of adhesion zones (Lima et al. 2013) and desmosome-like junctions (Nili et al. 2004) connecting granulosa cells were also observed in other mammalian species. The existence of cellular junctions between granulosa cells and oocyte enclosed into early PFs promotes the transfer of nutrients and metabolites to the oocyte and introduces low molecular weight signaling molecules that are essential for normal oocyte development (Santos et al. 2011). The transference of those substances also seemed to be performed by pinocytotic vesicles, once the presence of them protruding into the ooplasm from one GC to the other was observed in agoutis, similar as described for Ostrich (Struthio camelus, Madekurozwa \& Kimaro 2008) oocytes, where amorphous material was observed in the intercellular spaces of granulosa cells in primordial follicles. Further researchers may be performed to clarify that the endocytic process involved in the transfer of molecules, such as very low-density lipoprotein, is receptor-mediated.

Different from rats (Odor 1960), mice (Oakberg 1979) and guinea pigs (Adams \& Hertig 1964) no evident zona pellucida was observed at the primary follicle stage, but only in secondary ones in agoutis. Finally, general ovarian features found in this study are in concordance with previous studies conducted in the same species (Almeida et al. 2003).

\section{CONCLUSION}

We provided fundamental information regarding the population of preantral follicles in the ovary of Dasyprocta leporine, which will be useful for a better understanding of the folliculogenesis in this species, and for a further develop- 
ment and adaptation of assisted reproductive techniques for its multiplication and conservation.

\section{REFERENCES}

Adams E.C. \& Hertig A.T. 1964. Studies on guinea pig oocytes. I electron microscopic observations on the development of cytoplasmic organelles in oocytes of primordial and primary follicles. J. Cell. Biol. 21:397-427.

Almeida M.M., Carvalho M.A.M., Cavalcante Filho M.F., Miglino M.A. \& Menezes D.J.A. 2003. Estudo morfológico e morfométrico do ovário de cutias (Dasyprocta aguti, Linnaeus, 1766). Braz. J. Vet. Res. Anim. Sci. 40:55-62.

Antoine N., Lepoint A., Baeckeland E. \& Goessens G. 1987. Evolution of the rat oocyte nucleolus during follicular growth. Biol. Cell 59:107-112.

Antoine N., Thiry M. \& Goessens G. 1989. Ultrastructural and cytochemical studies on extranucleolar bodies in rat oocytes at the preovulatory follicle stage. Biol. Cell. 65:61-66. doi:10.1111/J.1768-322X.1989. TB00771.X.

Bernhard W. \& Rouiller C. 1956. Close topographical relationship between mitochondria and ergastoplasm of liver cells in a definitive phase of cellular activity. J. Biophys. Biochem. Cytol. 2:73-78.

Campos-Junior P.H.A., Assunção C.M., Carvalho B.C., Batista R.I.T.P., Garcia R.M.G. \& Viana J.H.M. 2012. Follicular populations, recruitment and atresia in the ovaries of different strains of mice. Reprod. Biol. 12(1):41-55.

Castelo T.S., Souza A.L.P., Lima G.L., Peixoto G.C.X., Campos L.B. \& Silva A.R. 2014. Interações entre diferentes tipos de estímulos elétricos e aparelhos de eletroejaculação na coleta do sêmen de cutias Dasyprocta azarae. In: VII Congresso Norte Nordeste de Reprodução Animal, Mossoró-RN. Acta Veterinaria Brasilica 8(2):47-48.

Chouinard L.A. 1971. A light and electron microscope study of the nucleolus during growth of the oocyte in the prepubertal mouse. Biol. Cell 41:35-42.

Dean J. 2002. Oocyte-specific genes regulate follicle formation, fertility and early mouse development. J. Reprod. Immunol. 53:171-180.

Dumollard R., Marangos P., Fitzharris G., Swann K., Duchen M. \& Carroll J. 2004. Sperm triggered $[\mathrm{Ca} 2+]$ oscillation and $\mathrm{Ca} 2+$ homeostasis in the mouse egg have an absolute requirement for mitochondrial ATP production. Development 131:3057-3067.

Eichenlaub-Ritter U., Wieczorek M., Lüke S. \& Seidel T. 2011. Age related changes in mitochondrial function and new approaches to study redox regulation in mammalian oocytes in response to age or maturation conditions. Mitochondrion 11:783-796.

Fair T., Hulshof S.C.J., Hyttel P., Greve T. \& Boland M. 1997. Oocyte ultrastructure in bovine primordial to early tertiary follicles. Anat. Embryol. 195:327-336.

Felipe A., Cabodevila J. \& Callejas S. 1999. Anatomico histological Characteristics of the ovary of the Coypu (Myocastor coypus). Anat. Histol. Embryol. 28:89-95.

Flamini M.A., Barbeito C.G., Gimeno E.J. \& Portiansky E.L., 2009. Histology, histochemistry and morphometry of the ovary of the adult plains viscacha (Lagostomus maximus) in different reproductive stages. Acta Zool. 90:390-400

Fortes E.A.M., Carvalho M.A.M., Almeida M.M., Conde-Júnior A.M., Cruz N.E.A. \& Assis-Neto A.C. 2005. Aspectos morfológicos da tuba uterina de cutias (Dasyprocta aguti, Mammalia: Rodentia). Braz. J. Vet. Res. Anim. Sci. 42(2):130-134.

Gil E., Forneris M., Dominguez S., Penissi A., Fogal T., Piezzi R.S. \& Scar-Dapane L. 2007. Morphological and endocrine study of the ovarianinterstitial tissue of viscacha (Lagostomus maximus). Anat. Rec. 290:788-794.

Gougeon A. \& Chainy G.B.N. 1987. Morphometric studies of small follicles in ovaries of women at different ages. J. Reprod. Fertil. 81:433-442.

Hirshfield A.N. 1989. Granulosa cell proliferation in very small follicles of cycling rats studied by long-term continuous tritiated-thymidine infusion. Biol. Reprod. 41:309-316.

Hosken F.M. \& Silveira A.C. 2001. Criação de cutias, p.21-22. Aprenda Fácil, Viçosa, MG.

IUCN 2016. Red List of Threatened Animals. IUCN, Gland, Switzerland and
Cambridge, UK. Versão 2011. Disponível em <http://www.iucnredlist. org> Accessed on Jun. 10, 2016.

Jensen F., Willis M.A., Albamonte M.S., Espinosa M.B. \& Vitullo A.D. 2006. Naturally suppressed apoptosis prevents follicular atresia and oocytereserve decline in the adult ovary of Lagostomus maximus (Rodentia, Caviomorpha). Reproduction 132:301-308.

Jimenez C.R., Araújo V.R., Penitente-Filho J.M., Azevedo J.L., Silveira R.G. \& Torres C.A.A. 2016. The base medium affects ultrastructure and survival of bovine preantral follicles cultured in vitro. Theriogenology 85:10191029.

Lima G.L., Santos E.A.A., Luz V.B., Silva A.R. \& Rodrigues A.P.R. 2013. Morphological Characterization of the Ovarian Preantral Follicle Population of Collared Peccaries (Tayassu tajacu Linnaeus, 1758). Anat. Histol. Embryol. 42:304-311. doi:10.1111/ahe.12021

Lopes C.A.P., Dos Santos R.R., Celestino J.J.H., Melo M.A., Chaves R.N., Campello C.C., Silva J.R.V., Báo S.N., Jewgenow K. \& Figueiredo J.R. 2009. Short-term preservation of canine preantral follicles: effects of temperature, medium and time. Anim. Reprod. Sci. 115:201-214.

Lopes L.H.R., Lucci C.M., Garcia M.P., Azevedo R.B. \& Báo S.N. 2006. Light microscopical and ultrastructural characterization of black howler monkey (Alouatta caraya) ovarian follicles. Anat. Histol. Embryol. 35: 196-201.

Lucci C.M., Amorim C.A., Rodrigues A.P.R., Figueiredo J.R., Báo S.N., Silva J.R.V. \& Gonçalves P.B.D. 1999. Study of preantral follicle population in situ and after mechanical isolation from caprine ovaries at different reproductive stages. Anim. Reprod. Sci. 56:223-236.

Madekurozwa M.C. \& Kimaro W.H. 2008. An Ultrastructural Characterization of the Ooplasm in Ovarian Follicles of the Immature Ostrich (Struthio camelus). Anat. Histol. Embryol. 37:214-218.

Mayor P., Bodmer R.E. \& Lopez-Bejar M. 2011. Functional anatomy of the female genital organs of the wild black agouti (Dasyprocta fuliginosa) female in the Peruvian Amazon. Anim. Reprod. Sci. 123:249-257.

Mcclellan K.A., Gosden R. \& Taketo T. 2003. Continuous loss of oocytes throughout meiotic prophase in the normal mouse ovary. Devel. Biol. 258:334-348.

Mollineau W.M., Adogwa A.O. \& Garcia G.W. 2008. A preliminary technique for electro-ejaculation of agouti (Dasyprocta leporina). Anim. Reprod. Sci. 7:92-108.

Mondadori R.G., Santin T.R., Fidelis A.A.G., Porfírio E.P. \& Báo S.N. 2010. Buffalo (Bubalus bubalis) pre-antral follicle population and ultrastructural characterization of antral follicle oocyte. Reprod. Domestic. Anim. 45:33-37.

Nili H., Mesbah F., Kafi M. \& Nasr Esfahani M.H. 2004. Light and transmission electron microscopy of immature camelus dromedarius oocyte. Anat. Histol. Embryol. 33:196-199.

Nogueira S.S.C. \& Nogueira-Filho S.L.G. 2011. Wildlife farming: an alternative to unsustainable hunting and deforestation in Neotropical forests? Biodiversity Conservation. 1:1-13. doi:10.1007/s10531-011-0047-7.

Oakberg E.F. 1979. Follicular growth and atresia in the mouse. In Vitro 15:41-49.

Odor D.L. 1960. Electron microscopic studies on ovarian oocytes and unfertilized tubal ova in the rat. J. Biophys. Biochem. Cytol. 7:567-574.

Oliveira M.F., Mess A., Ambrósio C.E., Dantas C.A.G., Favaron P.O. \& Miglino M.A. 2008. Chorioallantoic placentation in Galea spixii (Rodentia, Caviomorpha, Caviidae). Reprod. Biol. Endocrinol. 6:39. doi:10.1186/14777827-6-39

Paulini F., Silva R.C., Jivago J.L., Rôlo P. \& Lucci C.M. 2014. Ultrastructural changes in oocytes during folliculogenesis in domestic mammals. J. Ovarian Res. 7:102.

Praxedes E.C.G., Lima G.L., Silva A.M., Apolinário C.A., Bezerra J.A., Souza A.L., Oliveira M.F., Rodrigues A.P. \& Silva A.R. 2015. Characterisation and Cryopreservation of the Ovarian Preantral Follicle Population from Spix. Reprod. Fertil. doi.org/10.1071/RD15249. In publication.

Raturi A. \& Simmen T. 2013. Where the endoplasmic reticulum and the mitochondrion tie the knot: the mitochondria-associated membrane (MAM). Biochim. Biophys. Acta 1833:213-224.

Reis A.C.G., Gerbasi S.H.B., Martins C.,Machado M.R.F. \& Oliveira C.A. 2011. 
Morfologia do sistema genital feminino da paca (Cuniculus paca, Linnaeus, 1766). Braz. J. Vet. Res. Anim. Sci., 48(3):183-191.

Reis N.R., Peracchi A.L., Pedro W.A. \& Lima I.P. 2006. Mamíferos do Brasil, p.347-399. In: Oliveria J.A. \& Bonvicino C.R. (Eds), Sobre Ordem Rodentia, Londrina.

Reynaud K,, Halter S., Tahir Z., Thoumire S., Chebrout M. \& Chastant-Maillard S. 2010. Polyovular follicles. Gynecol. Obstet. Fertil. 38(6):395-397. doi: 10.1016/j.gyobfe.2010.04.008

Rodrigues R.F., Miglino M.A., Ferraz R.H.S. \& Morais-Pinto L. 2003. Placentação em cutias (Dasyprocta aguti Carleton, M.D.): aspectos morfológicos. Braz. J. Vet. Res. Anim. Sci. 40(2):133-137.

Sánchez-Toranzo G., Torres-Luque A., Gramajo-Bühler M.C. \& Bühler M.I. 2014. Histology of the ovary of Chinchilla lanigera in captivity. Anim. Reprod. Sci. 148:205-211.

Santos A.C., Bertassoli B.M., Viana D.V., Vasconcelos B.G., Oliveira M.F., Miglino M.A. \& Assis Neto A.C. 2014. The morphology of female genitalia in Galea spixii (Caviidae, Caviinae). Biosci. J. 30:6.

Santos R., Amorim C. \& Cecconi S. 2010. Cryopreservation of ovarian tissue: An emerging technology for female germline preservation of endangered species and breeds. Anim. Reprod. Sci. 122:151-163.

Santos R.R., Amorim C., Cecconi S., Fassbender M., Imhof M., Lornage J., Paris M., Schoenfeldt V., Martinez-Madrid B., Saragusty J. \& Arav A. 2011. Current progress in oocyte and embryo cryopreservation by slow freezing and vitrification. Reproduction 141:1-19.

Silva J.R.V., Van Den Hurk R., Costa S.H.F., Andrade E.R., Nunes A.P.A., Ferreira F.V.A., Lôbo R.N.B \& Figueiredo J.R. 2004. Survival and growth of goat primordial follicles after in vitro culture of ovarian cortical slic- es in media containing coconut water. Anim. Reprod. Sci. 81:273-286. doi:10.1016/j.anireprosci.2003.09.006

Silva M.A., Peixoto G.C.X., Santos E.A.A., Castelo T.S., Oliveira M.F. \& Silva A.R. 2011. Recovery and cryopreservation of epididymal sperm from agouti (Dasiprocta aguti) using powdered coconut water (ACP-109c) and Tris extenders. Theriogenology 76:1084-1089.

Sutovskỳ P., Jelinkov L., Antalikov L. \& Motlik J. 1993. Ultrastructural cytochemistry of the nucleus and nucleolus in growing rabbit oocytes. Biol. Cell 77:173-180.

Takeuchi I.K., Sonta S. \& Takeuchi Y.K. 1984. Association of perichromatin granules with nuclear pores of growing Chinese hamster oocytes. J. Electron Microsc. 33:388-394.

Van Aarde R.J. \& Skinner J.D. 1986. Functional anatomy of the ovariesof pregnant and lactating Cape porcupines, Hystrix africaeaustralis. J. Reprod. Fertil. 76(2):553-559.

Wanderley L.S., Luz H.K., Faustino L.R., Lima I.M., Lopes C.A., Silva A.R., Báo S.N., Campello C.C., Rodrigues A.P. \& Figueiredo J.R. 2012. Ultrastructural features of agouti (Dasyprocta aguti) preantral follicles cryopreserved using dimethyl sulfoxide, ethylene glycol and propanediol. Theriogenology $77(2): 260-267$.

Weir B.J. 1971. Some observations on reproduction in the female agouti (Dasyprocta aguti). J. Reprod. Fert. 24:203-211.

Weir B.J. \& Rowlands J.W. 1974. Functional anatomy of the hystricimorph ovary. Symp. Zool. Soc. Lond. 34:303-332.

Zuccotti M., Garagna S., Merico V., Monti M. \& Redi C.A. 2005. Chromatin organisation and nuclear architecture in growing mouse oocytes. Mol. Cell Endocrinol. 234:11-17. 